\begin{tabular}{c|c|c}
\hline $\begin{array}{c}\text { JURNAL PENELITIAN KEPERAWATAN } \\
\text { MEDIK }\end{array}$ & VOL. 1 NO. 2 & $\begin{array}{c}\text { EDITION: NOVEMBER 2018 - } \\
\text { APRIL 2019 }\end{array}$ \\
\hline & http://ejournal.delihusada.ac.id/index.php/JPKM & \\
\hline RECEIVED: 8 JANUARI 2019 & REVISED: 10 MARET 2019 & ACCEPTED: 15 MARET 2019 \\
\hline
\end{tabular}

\title{
PENGGUNAAN KATETER INTRAPLEURA (WATER SEALED DRAINAGE, INDWELLING PLEURAL CATHETER, PIGTAIL CATHETER) PADA PENATALAKSANAAN KANKER PARU DENGAN EFUSI PLEURA MASIF
}

\author{
Tamam Anugrah TAMSIL, Elisna SYAHRUDDIN*, Dicky SOEHARDIMAN* \\ Universitas Islam Sumatera Utara, JI. STM No. 77, Medan \\ *Universitas Indonesia, Persahabatan Hospital, Jakarta \\ Email: tamamtamsil@yahoo.com
}

\begin{abstract}
Massive pleural effusion is one of the problems in lung cancer treatment that cause death. The main treatment of cancer patient with massive pleural effusion is the placement of intrapleural catheter. This is a preliminary study which is aimed to assess tolerancies and efficacies of intrapleural catheter (WSD, IPC or pigtail catheter) in lung cancer with massive pleural effusion. This study is a retroscpective observational cohort study. Subjects are lung cancer patients with massive pleural effusion and catheterized with intrapleural catheter (WSD, IPC or pigtail catheter). The datas were taken from medical record at RSUP Persahabatan and assessed for tolerancies (acute or late complication) and efficacies ((length of hospital admission after catheter placement, duration and the reason of retraction) of intrapleural catheter. Tolerancies and efficacies of intrapleural catheter (WSD, IPC or pigtail catheter) in lung cancer patients with massive pleural effusion are quite good and safe. Prospective cohort studies are needed in the future to determine which type of intrapleural catheter is better for the treatment of massive pleural effusion in lung cancer patients.
\end{abstract}

Keyword : Lung cancer, massive pleural effusion, intrapleural catheter

\section{PENDAhUlUAN}

Efusi pleura merupakan salah satu penyulit yang sering ditemukan pada tatalaksana kasus keganasan. Angka tahan hidup keganasan dengan efusi pleura tersingkat didapatkan pada kanker paru dengan rata-rata hanya 3 bulan, sedangkan angka tahan hidup terlama pada kanker ovarium yaitu sekitar 12 bulan. Menurut American Thoracic Society (2000), insidens efusi pleura ganas diperkirakan lebih dari 150.000 kasus. Penelitian antara tahun 1994-1997 di Rumah Sakit Persahabatan Jakarta, ditemukan kasus EPG sebanyak 120 dari 229 (52.4\%) kasus efusi pleura (Mangunnegoro, 1998). Penelitian lain dengan metode kohort retrospektif dengan pengamatan antara tahun 2004 hingga 2007 di RS Persahabatan pada 535 pasien yang terdiagnosis kanker paru, didapatkan 31,2\% disertai dengan efusi pleura (Syahruddin, 2010). Penelitian angka tahan hidup berdasarkan kepositifan sitologi cairan pleura dan histopatologi biopsi pleura di RS Persahabatan periode 1 Januari 2010-31 Desember 2011, didapatkan hasil rerata angka tahan hidup pasien kanker paru dengan efusi pleura adalah 72,75 $\pm 123,95$ hari. Pada penelitian Mahsal dkk (2013), juga mendapatkan pasien yang memiliki hasil positif pada pemeriksaan cairan pleura dan histopatologi biopsi pleura memiliki angka tahan hidup yang lebih rendah dibandingkan pada pasien yang memiliki hasil negatif (overall survival time $40,42 \pm 42,828$ vs 104,88 $\pm 164,628$, p 0,01). 


\begin{tabular}{c|c|c}
\hline $\begin{array}{c}\text { JURNAL PENELITIAN KEPERAWATAN } \\
\text { MEDIK }\end{array}$ & VOL. 1 NO. 2 & $\begin{array}{c}\text { EDITION: NOVEMBER 2018 - } \\
\text { APRIL 2019 }\end{array}$ \\
\hline & http://ejournal.delihusada.ac.id/index.php/JPKM & \\
\hline RECEIVED: 8 JANUARI 2019 & REVISED: 10 MARET 2019 & ACCEPTED: 15 MARET 2019 \\
\hline
\end{tabular}

Efusi pleura masif merupakan salah satu masalah pada tatalaksana kanker paru dan dapat menyebabkan kematian. Tindakan pemasangan kateter intrapleura merupakan tatalaksana utama jika efusi pleura sangat produktif. American Thoracic Society (2000) menjelaskan bahwa kateter yang dapat digunakan antara lain kateter nelaton atau chest tube yang banyak digunakan pada pemasangan water sealed drainage (WSD). Pemasangan WSD pada pasien kanker paru sering menyebabkan lama rawat yang panjang, sehingga perlu difikirkan alternatif tindakan lain yang dapat berfungsi sama seperti punksi berulang, namun tanpa melibatkan tenaga medis dalam pelaksanaannya dan tanpa menyebabkan pasien harus dirawat di rumah sakit (Syahruddin, 2013). Divisi Onkologi Paru dan Mediastinum Departemen Pulmonologi dan Kedokteran Respirasi FK-UI bersama SMF Bedah Toraks dan Kardiovaskuler Rumah Sakit Persahabatan melakukan modifikasi dengan menggunakan kateter double lumen sebagai pengganti chest tube atau kateter nelaton, sehingga pemasangan WSD tidak lagi diperlukan. Pada perkembangan selanjutnya digunakan kateter jenis lain dengan teknik pemasangan di bawah jaringan subkutan, sehingga kateter terfiksasi baik dan memperkecil risiko infeksi yaitu indwelling pleural cathether (IPC), yang saat ini menjadi salah satu pilihan tatalaksana alternatif (Syahruddin, 2013).

Penelitian di Rumah Sakit Persahabatan periode 1 Januari 2010-31 Desember 2011 mendapatkan hasil proporsi pasien kanker paru dengan efusi pleura yang dilakukan pemasangan IPC hanya sekitar $1 \%$, namun pemasangan IPC yang tidak melihat status tampilan pasien dan ditanggungnya biaya pemasangan dalam jaminan kesehatan nasional, menjadikan penggunaannya semakin sering dalam beberapa tahun terakhir (Mahsal dkk, 2013). Efikasi pemasangan IPC dibandingkan dengan pemasangan chest tube yang diikuti dengan pleurodesis pada EPG telah banyak diteliti. Penelitian Lee dkk yang membandingkan 34 pasien yang terpasang IPC dengan 31 pasien yang terpasang chest tube diikuti dengan tindakan pleurodesis (proporsi IPC 52\%), mendapatkan hasil pasien yang ditatalaksana dengan pemasangan IPC, memiliki nilai tengah angka lama perawatan di rumah sakit yang lebih singkat yaitu 6,5 hari berbanding 18 hari pada pasien yang terpasang chest tube diikuti tindakan pleurodesis. Pada hasil penelitian ini juga didapatkan komplikasi setelah 3 bulan pemasangan yang lebih kecil pada pasien yang terpasang IPC yaitu 18,9\% berbanding $45,2 \%$ pada kelompok terpasang chest tube (Lee dkk, 2012).

Divisi Pulmonologi Intervensi dan Gawat Darurat Napas Departemen Pulmonologi dan Kedokteran Respirasi FK-UI pada beberapa tahun terakhir menggunakan kateter jenis pigtail untuk tujuan yang sama. Pigtail catheter berukuran lebih kecil, sehingga hanya sedikit menimbulkan rasa nyeri pasca pemasangan dan bila dipasang dengan prosedur yang benar, pada umumnya aman dengan risiko komplikasi yang relatif kecil (Gammie dkk, 1993). Berbagai perkembangan ini menyebabkan perlu dilakukan penelitian untuk menilai jenis kateter terbaik dalam hal toleransi dan efikasinya untuk penatalaksanaan kanker paru dengan efusi pleura masif. Penelitian ini merupakan penelitian pendahuluan untuk menilai toleransi dan efikasi dari berbagai jenis kateter intrapleura yang dapat digunakan

Oleh karenanya, penelitian ini bertujuan untuk mengetahui penggunaan (toleransi dan efikasi) kateter intrapleura (WSD, IPC dan pigtail catheter) pada penatalaksanaan kanker paru dengan efusi pleura masif. Selain itu, pasien dan umumn akan memperoleh pengetahuan tentang penatalaksanaan efusi pleura masif dengan kateter intrapleura yang nyaman bagi pasien dan aman karena risiko komplikasi yang kecil, sehingga dapat meningkatkan kualitas hidup pasien. 


\begin{tabular}{c|c|c}
\hline $\begin{array}{c}\text { JURNAL PENELITIAN KEPERAWATAN } \\
\text { MEDIK }\end{array}$ & VOL. 1 NO. 2 & $\begin{array}{c}\text { EDITION: NOVEMBER 2018 - } \\
\text { APRIL 2019 }\end{array}$ \\
\hline & http://ejournal.delihusada.ac.id/index.php/JPKM & \\
\cline { 2 - 2 } RECEIVED: 8 JANUARI 2019 & REVISED: 10 MARET 2019 & ACCEPTED: 15 MARET 2019 \\
\hline
\end{tabular}

\section{METODE PENELITIAN}

Desain penelitian ini adalah penelitian observasional atau kohort retrospektif dengan menggunakan data sekunder yaitu rekam medis pasien. Data dievaluasi hingga minimal 2 siklus kemoterapi atau radioterapi minimal 10 kali ( 2 bulan pemasangan) pada pasien yang terpasang IPC atau pigtail catheter, karena respons terapi sudah dapat dinilai. Jika data di rekam medik tidak lengkap akan dilakukan wawancara dengan kunjungan rumah atau lewat telefon pada pasien atau keluarganya.

Penelitian akan dilakukan di Departemen Pulmonologi dan Ilmu Kedokteran Respirasi FKUI/RSUP Persahabatan Jakarta. Penelitian akan dilakukan mulai Oktober 2015 sampai dengan Februari 2016 dengan populasi adalah semua pasien kanker paru dengan efusi pleura masif, pasien kanker paru dengan efusi pleura masif dan dirawat jalan atau inap di RS Persahabatan sejak 1 Januari 2012 sampai dengan 31 Desember 2015.

Adapun sampel penelitian ini adalahpPasien kanker paru dengan efusi pleura masif yang terpasang kateter intrapleura (WSD, IPC dan pigtail catheter) yang dirawat jalan atau inap di RS Persahabatan sejak 1 Januari 2012 sampai dengan 31 Desember 2015 dimana yang menjadi sampel adalah:

- Pasien kanker paru yang telah didiagnosis dengan pemeriksaan secara sitologi dan atau histologi dengan efusi pleura

- Pasien dengan kanker paru dengan efusi pleura masif yang terpasang kateter intrapleura (WSD, IPC atau pigtail catheter).

- Pasien dengan efusi pleura masif dengan penyebab selain kanker paru.

\section{HASIL PENELITIAN}

Karakteristik subjek penelitian adalah jenis kelamin, usia, jenis kanker paru dan terapi utama yang didapatkan pasien. Berdasarkan jenis kelamin, jenis kelamin laki-laki lebih banyak dari perempuan. Rata-rata usia subjek terutama usia dewasa adalah di atas 40 tahun. Jenis sel kanker paru, terbanyak adalah adenokarsinoma. Modaliti terapi terbanyak subjek adalah kemoterapi. Secara lebih dapat dilihat pada tabel 3.1
Tabel 3.1. Karakteristik subjek penelitian

\begin{tabular}{llcc}
\hline Variabel & & $\begin{array}{c}\text { Jumlah } \\
(\mathrm{n})\end{array}$ & Persentase (\%) \\
\hline Jenis kelamin & Laki-laki & 43 & 55,8 \\
Usia & Perempuan & 34 & 44,2 \\
& Median & 57.0 & \\
Jenis kanker paru & Range & $26-84$ & \\
& KPKSK & 5 & 6,5 \\
& Adenokarsinoma & 65 & 84,4 \\
\multirow{5}{*}{ Terapi } & KSS & 5 & 6,5 \\
& Lainnya & 2 & 2,6 \\
& Ya & 55 & 71,4 \\
& Kemoterapi & 25 & 32,5 \\
& Kemoradioterapi & 4 & 5,2 \\
& Radioterapi & 2 & 2,6 \\
& TKI & 17 & 22,1 \\
& TKI-Kemoterapi & 5 & 6,5 \\
& TKI-Kemoradioterapi & 2 & 2,6 \\
& Belum terapi & 22 & 28,6 \\
\hline
\end{tabular}

Berdasarkan jenis kateter intrapleura yang digunakan, terdapat pasien yang hanya memakai satu jenis kateter saja, tetapi beberapa pasien mengalami penggantian jenis kateter selama pengobatan. Jenis kateter intrapleura yang digunakan, secara jelas dapat diihat pada tabel 3.2.

Tabel 3.2. Jenis kateter intrapleura pada pasien kanker paru dengan efusi pleura.

\begin{tabular}{lccc}
\hline Jenis kateter intrapleura & & $\begin{array}{c}\text { Jumlah } \\
(\mathrm{n})\end{array}$ & $\begin{array}{c}\text { Persentase } \\
(\%)\end{array}$ \\
\hline Tidak memerlukan penggantian kateter & $\mathbf{5 7}$ & $\mathbf{7 4 , 0 2}$ \\
& WSD saja & 22 & 28,6 \\
& IPC saja & 34 & 44,2 \\
& $\begin{array}{l}\text { Pigtail catheter saja } \\
\text { Memerlukan penggantian kateter }\end{array}$ & 1 & 1,3 \\
& WSD diganti IPC & $\mathbf{2 0}$ & $\mathbf{2 5 , 9 7}$ \\
& 14 & 18,2 \\
& WSD diganti pigtail & 2 & 2,6 \\
& catheter & 2 & 1,3 \\
& IPC diganti WSD & 1 & \\
& Pigtail catheter diganti & 3 & 3,9 \\
\hline
\end{tabular}

Penggunaan jenis kateter berdasarkan karakteristik subjek, secara jelas dapat dilihat pada tabel 3.3

Tabel 3.3. Penggunaan kateter berdasarkan karakteristik subjek penelitian

\begin{tabular}{|c|c|c|c|c|c|c|c|c|}
\hline \multirow[t]{2}{*}{ Variabel } & & WSD & IPC & PTC & WSD $\rightarrow \mathbb{P C}$ & WSD $\rightarrow$ PT & $\mathrm{PT} \rightarrow \mathrm{PC}$ & $\mathrm{IPC} \rightarrow \mathrm{WSD}$ \\
\hline & & $n(\%)$ & $\mathrm{n}(\%)$ & $\mathrm{n}(\%)$ & $\mathrm{n}(\%)$ & $n(\%)$ & $\mathrm{n}(\%)$ & $\mathrm{n}(\%)$ \\
\hline \multirow[t]{2}{*}{$\begin{array}{l}\text { Jenis } \\
\text { kelamin }\end{array}$} & Lakk-laki & $13(16,9)$ & $21(27,3)$ & $0(0,0)$ & $7(9,1)$ & $0(0,0)$ & $1(1,3)$ & $1(1,3)$ \\
\hline & Perempuan & $9(11,7)$ & $13(16,9)$ & $1(1,3)$ & $7(9,1)$ & $2(2,6)$ & $2(2,6)$ & $0(0,0)$ \\
\hline \multirow[t]{2}{*}{ Usia } & Range (26-84 thin) & $22(28,6)$ & $34(44,2)$ & $1(1,3)$ & $14(18,2)$ & $2(2,6)$ & $3(3,9)$ & $1(1,3)$ \\
\hline & Median $(57,0 \mathrm{thn})$ & & & & & & & \\
\hline \multirow[t]{4}{*}{$\begin{array}{l}\text { Jenis kanker } \\
\text { paru }\end{array}$} & KPKSK & $2(2,6)$ & $2(2,6)$ & $0(0,0)$ & $0(0,0)$ & $0(0,0)$ & $1(1,3)$ & $0(0,0)$ \\
\hline & Adenokarsinoma & $18(23,4)$ & $29(37,7)$ & $1(1,3)$ & $12(15,6)$ & $2(2,6)$ & $2(2,6)$ & $1(1,3)$ \\
\hline & KSS & $1(1,3)$ & $3(3,9)$ & $0(0,0)$ & $1(1,3)$ & $0(0,0)$ & $0(0,0)$ & $0(0,0)$ \\
\hline & Lainnya & $1(1,3)$ & $0(0,0)$ & $0(0,0)$ & $1(1,3)$ & $0(0,0)$ & $0(0,0)$ & $0(0,0)$ \\
\hline \multirow[t]{8}{*}{ Terapi } & Ya & $11(14,3)$ & $28(36,4)$ & $1(1,3)$ & $11(14,3)$ & $0(0,0)$ & $3(3,9)$ & $1(1,3)$ \\
\hline & Kemoterapi & $5(6,5)$ & $13(16,9)$ & $0(0,0)$ & $4(5,2)$ & $0(0,0)$ & $2(2,6)$ & $1(1,3)$ \\
\hline & Kemoradioterapi & $2(2,6)$ & $2(2,6)$ & $0(0,0)$ & $0(0,0)$ & $0(0,0)$ & $0(0,0)$ & $0(0,0)$ \\
\hline & Radioterapi & $0(0,0)$ & $0(0,0)$ & $0(0,0)$ & $1(1,3)$ & $0(0,0)$ & $1(1,3)$ & $0(0,0)$ \\
\hline & TKI & $3(3,9)$ & $8(10,4)$ & $1(1,3)$ & $5(6,5)$ & $0(0,0)$ & $0(0,0)$ & $0(0,0)$ \\
\hline & $\begin{array}{l}\text { TKI-Kemoterapi } \\
\text { TKI- }\end{array}$ & $1(1,3)$ & $3(3,9)$ & $0(0,0)$ & $1(1,3)$ & $0(0,0)$ & $0(0,0)$ & $0(0,0)$ \\
\hline & Kemoradioterapi & $0(0,0)$ & $2(2,6)$ & $0(0,0)$ & $0(0,0)$ & $0(0,0)$ & $0(0,0)$ & $0(0,0)$ \\
\hline & Belum terapi & $11(14,3)$ & $6(7,8)$ & $0(0,0)$ & $3(3,9)$ & $2(2,6)$ & $0(0,0)$ & $0(0,0)$ \\
\hline
\end{tabular}




\begin{tabular}{c|c|c}
\hline $\begin{array}{c}\text { JURNAL PENELITIAN KEPERAWATAN } \\
\text { MEDIK }\end{array}$ & VOL. 1 NO. 2 & $\begin{array}{c}\text { EDITION: NOVEMBER 2018 - } \\
\text { APRIL 2019 }\end{array}$ \\
\hline & http://ejournal.delihusada.ac.id/index.php/JPKM & \\
\hline RECEIVED: 8 JANUARI 2019 & REVISED: 10 MARET 2019 & ACCEPTED: 15 MARET 2019 \\
\hline
\end{tabular}

Komplikasi akut adalah komplikasi yang terjadi kurang dari 7 hari pasca pemasangan kateter intrapleura. Tidak ditemukan komplikasi akut berupa alergi terhadap kateter atau pneumotoraks (tabel 3.4).

Tabel 3.4 Komplikasi akut pemakaian kateter intrapleura

\begin{tabular}{|c|c|c|}
\hline Komplikasi akut & Jumlah (n\%) & Persentase (\%) \\
\hline Ada & 54 & 70,1 \\
\hline Nyeri lokasi pemasangan & 45 & 58,4 \\
\hline Infeksi (selulitis) & 3 & 3,9 \\
\hline Masalah kateter & 3 & 3,9 \\
\hline Emfisema subkutis & 3 & 3,9 \\
\hline Tidak ada & 23 & 29,9 \\
\hline
\end{tabular}

Pada tabel 3.5 dapat dilihat secara jelas komplikasi akut yang terjadi berdasarkan jenis kateter yang digunakan. Masalah kateter pada penelitian berupa kateter rembes dan jahitan longgar pada 2 subjek terpasang WSD dan 1 subjek saat pemakaian pigtail catheter.

Tabel 3.5. Gambaran komplikasi akut berdasarkan jenis kateter yang terpasang.

\begin{tabular}{|c|c|c|c|}
\hline \multirow[t]{2}{*}{ Komplikass alkut } & WSD & $\mathrm{IPC}$ & PTC \\
\hline & $n(\%)$ & $n(\%)$ & $n(\%)$ \\
\hline Ada & $35(45,5)$ & $16(19,4)$ & $3(3,9)$ \\
\hline Nyerilokasi pemasangan & $28(36,4)$ & $15(19,5)$ & $2\{2,6)$ \\
\hline Infeksi (salulitis) & $2(2,6)$ & $1(1,3)$ & $0 \mid 0,0)$ \\
\hline Masaliah katater & $2(2,6)$ & $0(0,0)$ & $1\{1,3\}$ \\
\hline Emfisema subkutis & $3(3,9)$ & $0(0,0)$ & $0(0,0)$ \\
\hline Tidak ada & $3(3,9)$ & $19(24,7)$ & $1[1,3]$ \\
\hline
\end{tabular}

Komplikasi lanjut adalah komplikasi yang terjadi setelah 7 hari pasca pemasangan kateter intrapleura. Didapatkan angka kejadian komplikasi lanjut lebih kecil bila dibandingkan dengan komplikasi akut. Komplikasi lanjut berupa needle tract metastasis tidak ditemukan (tabel 3.6).

Tabel 3.6. Komplikasi lanjut selama pemakaian kateter intrapleura.

\begin{tabular}{llcc}
\hline Komplikasi kronik & Jumlah (n\%) & Persentase (\%) \\
\hline Ada & Nyeri lokasi kateter & $\mathbf{4 2}$ & 54,5 \\
& (menetap/bertambah) & 23 & 29,9 \\
& Alergi kateter & 1 & 1,3 \\
& Hidropneumotoraks & 2 & 2,6 \\
& Infeksi: & 10 & 13,0 \\
& Empiema & 4 & 5,2 \\
& Selulitis & 6 & 7,8 \\
& Masalah kateter & 5 & 6,5 \\
& Emfisema subkutis & 1 & 1,3 \\
Tidak ada & & $\mathbf{3 5}$ & $\mathbf{4 5 , 5}$ \\
\hline
\end{tabular}

Pada tabel 3.7 dapat dilihat komplikasi lanjut yang terjadi. Masalah pada kateter pada 4 subjek yang memakai IPC terdiri dari 1 subjek dengan kateter tersumbat, kateter rembes 2 subjek dan jahitan longgar 1 subjek. Satu subjek mengalami kateter tercabut saat pemakaian WSD.

Tabel 3.7 Gambaran komplikasi lanjut berdasarkan jenis kateter yang terpasang.

\begin{tabular}{lccc}
\hline Komplikasi lanjut & WSD & PC & PTC \\
\cline { 2 - 4 } & $\mathrm{n}(\%)$ & $\mathrm{n}(\%)$ & $\mathrm{n}(\%)$ \\
\hline Ada & $21(27,3)$ & $20(26,0)$ & $1(1,3)$ \\
Nyerilokasi kateter (bertambah) & $16(20,8)$ & $7(9,1)$ & $0(0,0)$ \\
Alergi kateter & $1(1,3)$ & $0(0,0)$ & $0(0,0)$ \\
Hidropneumotoraks & $1(1,3)$ & $1(1,3)$ & $0(0,0)$ \\
Infeksi: & $1(1,3)$ & $8(10,4)$ & $1(1,3)$ \\
Empiema & $0(0,0)$ & $3(3,9)$ & $1(1,3)$ \\
Selulitis & $1(1,3)$ & $5(6,5)$ & $0(0,0)$ \\
Masalah kateter & $1(1,3)$ & $4(5,2)$ & $0(0,0)$ \\
Emfisema sublutis & $1(1,3)$ & $0(0,0)$ & $0(0,0)$ \\
Tidak & $8(10,4)$ & $24(31,2)$ & $3(3,9)$ \\
\hline
\end{tabular}

Pada penelitian ini didapatkan lama pemakaian kateter terbanyak kurang dari 1 bulan dan lama rawat kurang dari 2 minggu. Secara lebih jelas dapat dilihat pada tabel 3.8

Tabel 3.8. Lama pemakaian, lama rawat dan posisi pemasangan kateter

\begin{tabular}{lcc}
\hline Variabel & Jumlah $(\mathrm{n})$ & Persentase $(\%)$ \\
\hline Lama pemakaian & & \\
$<30$ hari & 35 & 45,5 \\
$31-60$ hari & 15 & 19,5 \\
$>60$ hari & 27 & 35,1 \\
Median & 30 hari & \\
Range & $2-310$ hari & \\
Lama rawat pasca pasang & & \\
$<15$ hari & 51 & 66,2 \\
15-30 hari & 20 & 26,0 \\
$>30$ hari & 6 & 7,8 \\
Median & 10 hari & \\
Range & $1-72$ hari & \\
Posisi kateter intrapleura & & \\
Kanan & 45 & 58,4 \\
Kiri & 32 & 41,6 \\
\hline
\end{tabular}

Posisi pemasangan kateter pada dinding dada, secara umum lebih banyak terpasang pada sisi sebelah kanan dan tidak terdapat pemasangan kateter pada sisi bilateral. Pada tabel 3.9. dapat dilihat secara jelas lama pemakaian, lama rawat pasca pemasangan dan posisi pemasangan kateter berdasarkan jenis kateter yang digunakan.

Tabel 3.9. Lama penggunaan, lama rawat dan posisi kateter berdasarkan jenis kateter 


\begin{tabular}{c|c|c}
\hline $\begin{array}{c}\text { JURNAL PENELITIAN KEPERAWATAN } \\
\text { MEDIK }\end{array}$ & VOL. 1 NO. 2 & $\begin{array}{c}\text { EDITION: NOVEMBER 2018 - } \\
\text { APRIL 2019 }\end{array}$ \\
\hline & http://ejournal.delihusada.ac.id/index.php/JPKM & \\
\hline RECEIVED: 8 JANUARI 2019 & REVISED: 10 MARET 2019 & ACCEPTED: 15 MARET 2019 \\
\hline
\end{tabular}

\begin{tabular}{|c|c|c|c|c|c|c|c|}
\hline \multirow[t]{2}{*}{ Variabel } & WSD & IPC & PTC & WSD $\rightarrow \mathrm{IPC}$ & $\mathrm{WSD} \rightarrow \mathrm{PT}$ & $\mathrm{PT} \rightarrow \mathrm{IPC}$ & $\mathrm{IPC} \rightarrow \mathrm{WSD}$ \\
\hline & $\mathrm{n}(\%)$ & $\mathrm{n}(\%)$ & $\mathrm{n}(\%)$ & $\mathrm{n}(\%)$ & $\mathrm{n}(\%)$ & $\mathrm{n}(\%)$ & $\mathrm{n}(\%)$ \\
\hline \multicolumn{8}{|c|}{ Lama penggunaan } \\
\hline$<30$ hari & $17(22,1)$ & $10(13,0)$ & $0(0,0)$ & $7(9,1)$ & $0(0,0)$ & $1(1,3)$ & $0(0,0)$ \\
\hline 30-60 hari & $1(1,3)$ & $9(11,7)$ & $0(0,0)$ & $3(3,9)$ & $2(2,6)$ & $0(0,0)$ & $0(0,0)$ \\
\hline$>60$ hari & $4(5,2)$ & $15(19,5)$ & $1(1,3)$ & $4(5,2)$ & $0(0,0)$ & $2(2,6)$ & $1(1,3)$ \\
\hline \multicolumn{8}{|c|}{ Lama rawat pasca pasang } \\
\hline$<15$ hari & $9(11,7)$ & $32(41,6)$ & $1(1,3)$ & $5(6,5)$ & $1(1,3)$ & $2(2,6)$ & $1(1,3)$ \\
\hline 15-30 hari & $11(14,3)$ & $2(2,6)$ & $0(0,0)$ & $6(7,8)$ & $0(0,0)$ & $1(1,3)$ & $0(0,0)$ \\
\hline$>30$ hari & $2(2,6)$ & $O(0,0$ & $0(0,0)$ & $3(3,9)$ & $1(1,3)$ & $0(0,0)$ & $0(0,0)$ \\
\hline \multicolumn{8}{|c|}{ Posisi kateter intrapleura } \\
\hline Kanan & $12(15,6)$ & $22(28,6)$ & $1(1,3)$ & $7(9,1)$ & $2(2,6)$ & $0(0,0)$ & $1(1,3)$ \\
\hline Kiri & $10(13,0)$ & $12(15,6)$ & $0(0,0)$ & $7(9,1)$ & $O(0,0)$ & $3(3,9)$ & $0(0,0)$ \\
\hline
\end{tabular}

\section{Alasan pencabutan kateter intrapleura}

Pada penelitian ini didapatkan, sebanyak 70 pasien $(90,9 \%)$ sudah dilakukan pencabutan kateter intrapleura, sedangkan 7 pasien lagi $(9,1 \%)$ kateternya masih terpasang saat penelitian ini selesai. Alasan pencabutan kateter yang terbanyak adalah karena produksi cairan pleura sudah minimal. Secara lebih jelas lihat tabel 3.10

Tabel 3.10. Alasan pencabutan kateter intrapleura

\begin{tabular}{lcc}
\hline Alasan pencabutan kateter & Jumlah (n) & Persentase (\%) \\
\hline Produksi minimal & 36 & 46,75 \\
Komplikasi & 12 & 15,6 \\
Meninggal & 20 & 26,0 \\
Kateter masih terpasang & 7 & 9,1 \\
Pulang permintaan sendiri & 2 & 2,6 \\
\hline
\end{tabular}

Pada tabel 3.11 dapat dilihat secara jelas beberapa alasan pencabutan kateter pada pasien berdasarkan jenis kateter yang dipakai. Alasan penggantian kateter pada kelompok yang memerlukan penggantian kateter yaitu produksi cairan pleura yang masih banyak untuk mempersingkat masa rawat atau komplikasi yang tidak teratasi Pada tabel tersebut alasan pencabutan kateter pada kelompok yang memerlukan penggantian kateter adalah alasan pencabutan kateter yang terakhir dipasang.
Tabel 3.11. Alasan pencabutan kateter berdasarkan pasien berdasarkan jenis kateter

\begin{tabular}{|c|c|c|c|c|c|c|c|}
\hline Alassan pencabutan & WSD & $\mathrm{PC}$ & PTC & WSD $\rightarrow$ IPC & WSD-PT & $\mathrm{PT} \rightarrow \mathrm{IPC}$ & $\mathbb{P P C} \rightarrow$ WSD \\
\hline kateter intrapleura & $n(\%)$ & $\mathbb{n}(\%)$ & $\mathbb{n}(\%)$ & $\mathbb{n}(\%)$ & $\mathfrak{n}(\%)$ & $\mathbb{n}(\%)$ & $\mathbb{n}(\%)$ \\
\hline $\begin{array}{l}\text { Produlusic cirran } \\
\text { minimal }\end{array}$ & $14(18,2)$ & $14(18,2)$ & $1(1,3)$ & $7(9,1)$ & $0(0,0)$ & $0(0,0)$ & $0(0,0)$ \\
\hline Komplikasi & $2(2,6)$ & $2(2,6)$ & $0(0,0)$ & $4(5,2)$ & $1(1,3)$ & $3(3,9)$ & $v(0,0)$ \\
\hline Meninggal & $4(5,2)$ & $13(16,9)$ & $0(0,0)$ & $1(1,3)$ & $1(1,3)$ & $0(0,0)$ & $1(1,3)$ \\
\hline Kateter mas & $0(0,0)$ & $5(6,5)$ & $0(0,0)$ & $2(2,6)$ & $0(0,0)$ & $0(0,0)$ & $0(0,0)$ \\
\hline $\begin{array}{l}\text { Pulang permintaan } \\
\text { sendiri }\end{array}$ & $2(2,6)$ & $0(0,0)$ & $0(0,0)$ & $0(0,0)$ & $0(0,0)$ & $0(0,0)$ & $0(0,0)$ \\
\hline
\end{tabular}

\section{Analisis Variabel}

Pada penelitian ini, data yang dapat dianalisis terbatas disebabkan oleh karena sebaran data yang tidak merata, sehingga ketiga jenis kateter tidak dapat dibandingkan mana yang lebih baik. Pada subjek yang menggunakan pigtail catheter, analisis tidak dilakukan karena jumlah subjek terlalu kecil. Pada tabel 3.12 dapat dilihat hubungan antara jenis kateter, dengan terjadinya komplikasi akut dan lanjut untuk jenis kateter WSD dan IPC secara keseluruhan, dengan memasukkan juga komplikasi yang terjadi pada kelompok yang mengalami pergantian kateter.

Tabel 3.12. Hubungan pemakaian WSD dan IPC dengan komplikasi akut dan lanjut

\begin{tabular}{lccc}
\hline Jenis kateter & Komplikasi akut & & nilai $\mathrm{p}$ \\
\cline { 2 - 3 } & Ada & Tidak & \\
\hline WSD & 35 & 3 & 0,000 \\
IPC & 16 & 19 & \\
\hline Jenis kateter & Komplikasi lanjut & & nilai p \\
\cline { 2 - 3 } & Ada & Tidak & \\
\hline WSD & 21 & 8 & 0,037 \\
IPC & 20 & 24 & \\
\hline
\end{tabular}

Pada pemakaian pigtail catheter secara keseluruhan, komplikasi akut ditemukan pada 3 subjek dengan komplikasi berupa nyeri lokasi pemasangan kateter pada 2 subjek dan 1 subjek dengan masalah pada kateter. Komplikasi lanjut didapatkan pada 1 subjek berupa empiema. 


\begin{tabular}{c|c|c}
\hline $\begin{array}{c}\text { JURNAL PENELITIAN KEPERAWATAN } \\
\text { MEDIK }\end{array}$ & VOL. 1 NO. 2 & $\begin{array}{c}\text { EDITION: NOVEMBER 2018 - } \\
\text { APRIL 2019 }\end{array}$ \\
\hline & http://ejournal.delihusada.ac.id/index.php/JPKM & \\
\hline RECEIVED: 8 JANUARI 2019 & REVISED: 10 MARET 2019 & ACCEPTED: 15 MARET 2019 \\
\hline
\end{tabular}

Pada tabel 3.13 dapat dilihat secara jelas hubungan antara jenis kateter WSD dan IPC saja dengan lama rawat pasca pemasangan dan lama pemakaian kateter.

Tabel 3.13. Hubungan pemakaian WSD dan IPC dengan lama rawat dan lama pemakaian

\begin{tabular}{lrrcc}
\hline Jenis kateter & \multicolumn{3}{c}{ Lama rawat pasca pasang } & nilai p \\
\cline { 2 - 4 } & $\begin{array}{l}<15 \\
\text { hari }\end{array}$ & $\begin{array}{l}15-30 \\
\text { hari }\end{array}$ & $>30$ hari & \\
\hline WSD & 9 & 11 & 2 & 0,452 \\
IPC & 32 & 2 & 0 & 0,000 \\
\hline Jenis kateter & \multicolumn{3}{c}{ Lama pemakaian kateter } & nilai p \\
\cline { 2 - 4 } & $<$ & & & \\
& 30 & $30-60$ & $>60$ hari & \\
\hline WSD & hari & hari & 4 & 0,002 \\
IPC & 17 & 1 & 15 & 0,025 \\
& 10 & 9 & & \\
\hline
\end{tabular}

Berdasarkan lama pemakaian pigtail catheter secara keseluruhan, terdapat 2 subjek dengan pemakaian pigtail catheter kurang dari 30 hari $(33,33 \%), 2$ subjek (33,33\%) antara 30-60 hari dan 2 subjek lebih dari 60 hari. Berdasarkan lama rawat pasca pemasangan kateter, didapatkan seluruh subjek memliki lama rawat pasca pemasangan kateter kurang dari 15 hari.

Pada tabel 3.14 terlihat hubungan antara jenis kateter WSD dan IPC dengan respons terapi. Respons terapi pada tabel ini merupakan perbaikan berupa produksi cairan sudah minimal $(<50 \mathrm{ml}$ ) yang menjadi salah satu alasan pencabutan kateter.

Pada subjek yang terpasang pigtail catheter, hanya satu subjek $(16,67 \%)$ yang kateternya dicabut karena respons terapi, lima subjek lainnya kateter dicabut karena komplikasi atau meninggal.

Tabel 3.14. Hubungan antara pemakaian WSD atau IPC dengan respons terapi

\begin{tabular}{lccc}
\hline \multirow{2}{*}{ Jenis kateter } & \multicolumn{2}{c}{ Respons terapi } & nilai p \\
& Ya & Tidak & \\
\hline WSD & 14 & 8 & 0,532 \\
IPC & 14 & 20 & 0,060 \\
\hline
\end{tabular}

\section{PEMBAHASAN}

Kelemahan penelitian ini adalah tidak terdapatnya kelompok pembanding untuk menilai toleransi dan efikasi penatalaksanaan efusi pleura pada kanker paru, misalnya tindakan pleurodesis dengan penggunaan berbagai zat sklerosan, yang merupakan standar emas tatalaksana EPG (Antunes dkk, 2003). Pemasangan kateter intrapleura jangka panjang merupakan salah satu alternatif tatalaksana EPG sejak tahun 1997 dan penggunaannya berdasarkan hasil-hasil penelitian cukup aman dengan angka komplikasi yang kecil dan dapat memperkecil biaya perawatan serta risiko terjadinya infeksi nosokomial (Putnam dkk, 1999; Lui dkk, 2015; Davies dkk, 2012).

\section{Karakteristik subjek penelitian}

Pada penelitian ini didapatkan jenis kelamin laki-laki lebih banyak dibandingkan perempuan sama seperti hasil penelitian lain. Hasil ini hampir sama dengan penelitian Syahruddin dkk (2010) pada pasien kanker paru dengan efusi pleura masif di RSUP Persahabatan tahun 2004-2007, yaitu dari 165 pasien, jenis kelamin laki-laki lebih banyak dibandingkan perempuan yaitu sebesar $63,5 \%$. Penelitian Mahzal dkk (2013), pada pasien kanker paru dengan efusi pleura didapatkan bahwa jenis kelamin laki-laki lebih banyak, yaitu $66 \%$. Hasil penelitian ini berbeda dengan penelitian Trembley dkk, (2006) dengan hasil dari 250 pasien kanker paru dengan efusi pleura, didapatkan jenis kelamin perempuan lebih banyak dari laki-laki $(50,4 \%)$. Penyebab lakilaki lebih banyak terkena kanker paru dengan efusi pleura lebih banyak tidak didapat etiologi secara pasti. Diduga kemungkinan penyebabnya adalah karena jumlah kasus lakilaki memang lebih banyak.

Pada penelitian ini didapatkan usia rata-rata pasien 55,20 tahun, median 57 tahun, dengan usia termuda 26 tahun serta usia tertua 84 tahun. Hasil penelitian ini hampir sama dengan penelitian Syahruddin dkk (2010). yang mendapatkan median usia 55 tahun, dengan usia termuda 18 tahun dan tertua 81 tahun. Penelitian Mahzal dkk (2013), mendapatkan rentang usia terbanyak pada pasien kanker paru dengan efusi pleura adalah 40-60 tahun, 


\begin{tabular}{c|c|c}
\hline $\begin{array}{c}\text { JURNAL PENELITIAN KEPERAWATAN } \\
\text { MEDIK }\end{array}$ & VOL. 1 NO. 2 & $\begin{array}{c}\text { EDITION: NOVEMBER 2018 } \\
\text { APRIL 2019 }\end{array}$ \\
\hline & http://ejournal.delihusada.ac.id/index.php/JPKM & \\
\cline { 2 - 2 } RECEIVED: 8 JANUARI 2019 & ACCEPTED: 15 MARET 2019 \\
\hline
\end{tabular}

sebesar 92\%. Penelitian Tremblay dkk, (2006) mendapatkan median usia pasien kanker paru dengan efusi pleura 64 tahun, dengan usia termuda 33 tahun dan tertua 90 tahun. Persamaan usia juga dikaitkan dengan rerata usia penderita kanker paru secara umum.

Jenis kanker paru terbanyak yang ditemukan pada penelitian ini adalah adenokarsinoma diikut dengan karsinoma sel skuamosa dan KPKSK tetapi tidak ditemukan kanker paru dengan jenis karsinoma sel besar (KSB). Hasil penelitian ini hampir sama dengan penelitian Syahruddin dkk (2010). yang mendapatkan jenis kanker yang terbanyak adalah adenokarsinoma $90,4 \%$, diikuti KSS 6,6\%, KSB $2,5 \%$ dan adenoskuamosa sebanyak $0,3 \%$. Mahzal dkk, (2013) pada penelitiannya mendapatkan jenis sel kanker terbanyak adalah adenokarsinoma sebesar $82 \%$ dengan modaliti sitologi cairan pleura yang positif sebesar 54,8\%. Hasil penelitian ini hampir sama dengan beberapa penelitian dari luar seperti Bielsa dkk (2008), yang menyebutkan pada 97 pasien dengan sitologi cairan pleura positif terdiri dari jenis adenokarsinoma $61,9 \%$, KSS $12,4 \%$, karsinoma sel kecil 10,3\% dan jenis lain (terdapat sel ganas dan adenoskuamosa 15,9\%). Penelitian lainnya oleh Sallach dkk (2002), mendapatkan kepositifan sitologi CP sekitar $60 \%$ pada efusi pleura ganas, dengan jenis adenokarsinoma yang terbanyak. Hubungan antara jenis sel kanker dengan terjadinya efusi pleura berdasarkan patogenesis efusi pleura dapat diterangkan dengan karakter dari adenokarsinoma paru yang biasanya tumbuh di bagian perifer sehingga kemungkinan invasi ke pleura lebih besar. Penelitian lain juga menunjukkan kecenderungan jenis adenokarsinoma lebih cepat bermetastasis (Miserocchi, 1997; Porcel dkk, 2006).

Pilihan terapi untuk penatalaksanaan kanker paru dengan efusi pleura adalah terapi sistemik untuk kanker yaitu kemoterapi atau targeted terapi. Sesuai dengan kepustakaan, pada penelitian ini didapatkan modaliti terapi yang paling banyak digunakan adalah kemoterapi dan pemberian EGFR-TKI. Hasil penelitian menunjukkan jumlah subjek yang mengalami respons terapi yaitu dengan berkurangnya produksi cairan pleura, kurang dari 50 persen. Hal ini dapat terjadi karena berkaitan dengan respon terapi, pada evaluasi respons kemoterapi, efusi pleura termasuk dalam kelompok truly nonmeasurable lession, sehingga meskipun masih ada efusi setelah terapi 2 siklus tetap dapat dinilai menetap (stable disesase)(Park dkk, 2003).

\section{Jenis kateter intrapleura}

Penggunaan IPC di RSUP Persahabatan untuk penatalaksanaan efusi pleura pada pasien kanker paru dimulai sejak tahun 2012. Sejak itu penggunaannya menjadi pilihan dengan pertimbangan biaya dan memperpendek masa rawat. Namun, pada pada beberapa kondisi WSD tetap digunakan sebelum muncul jenis kater lain yaitu pigtail chateter. Sebagian pasien dengan pertimbangan klinis dan biaya dilakukan penggantian jenis kateter. Kelompok pasien yang memerlukan penggantian kateter paling banyak adalah WSD diganti IPC. Alasan penggantian WSD terbanyak adalah cairan pleura yang masih banyak dan diharapkan penggantian kateter dapat mempersingkat lama rawat pasien. Hasil yang berbeda didapatkan pada penelitian Mahzal dkk, (2013) melaporkan penggunaan WSD merupakan jenis kateter yang banyak digunakan. Berbagai hasil penelitian yang terangkum dalam ulasan artikel oleh Lui dkk (2015) menyatakan pemakaian kateter intrapleura jangka panjang, misalnya IPC, dapat dijadikan alternatif tatalaksana EPG selain pleurodesis, dengan komplikasi yang kecil, dapat digunakan pada keadaan trapped lung dan dapat mempersingkat lama rawat di rumah sakit. Penelitian tentang penggunaan IPC atau pigtail catheter pada tatalaksana EPG belum pernah dilakukan, tetapi penggunaan povidon iodin dan dosisiklin sebagai bahan pleurodesis pernah dilakukan pada tatalaksana EPG. Hasil penelitian ini mendapatkan efektivi pleurodesis dengan povidon iodin tidak berbeda dengan doksisiklin dengan angka keberhasilan 


\begin{tabular}{c|c|c}
\hline $\begin{array}{c}\text { JURNAL PENELITIAN KEPERAWATAN } \\
\text { MEDIK }\end{array}$ & VOL. 1 NO. 2 & $\begin{array}{c}\text { EDITION: NOVEMBER 2018 - } \\
\text { APRIL 2019 }\end{array}$ \\
\hline & http://ejournal.delihusada.ac.id/index.php/JPKM & \\
\hline RECEIVED: 8 JANUARI 2019 & REVISED: 10 MARET 2019 & ACCEPTED: 15 MARET 2019 \\
\hline
\end{tabular}

pleurodesis $68 \%$ pada kelompok povidon iodin dan $62 \%$ pada kelompok doksisiklin. Efek samping yang terjadi lebih kecil pada kelompok povidon iodin (Barus dkk, 2006).

\section{Komplikasi akut dan lanjut selama pemakaian kateter intrapleura}

Komplikasi akut penggunaan kateter intrapleura merupakan komplikasi yang terjadi kurang dari 7 hari pasca pemasangan kateter intrapleura. Pada penelitian ini didapatkan $70,1 \%$ mengalami komplikasi akut dengan komplikasi terbanyak adalah nyeri lokasi pemasangan. Komplikasi akut pada penelitian ini hampir sama dengan hasil penelitian yang menyatakan bahwa komplikasi akut yang sering ditemukan pada pemakaian kateter intrapleura adalah nyeri pada lokasi pemasangan, infeksi jaringan lunak sekitar kateter (selulitis), alergi, pneumotoraks dan emfisema subkutis (Lui dkk, 2015). Hasil penelitian Parulekar dkk, (2001) yang menyatakan tidak terdapat hubungan yang bermakna pada pemakaian WSD atau pigtail catheter dengan terjadinya komplikasi pasca pemasangan (nilai $p=0,082$ ). Pada penelitian ini meskipun ada penggunaan pigtail catheter namun tidak dapat dianalisis karena kecilnya jumlah subjek.

Komplikasi lanjut pemakaian kateter intrapleura adalah komplikasi yang terjadi setelah 7 hari pasca pemasangan kateter intrapleura. Hasil pada penelitian ini sesuai dengan beberapa literatur yang mengatakan bahwa komplikasi lanjut yang sering ditemukan pada pemakaian kateter intrapleura adalah nyeri lokasi pemasangan kateter yang menetap, infeksi misalnya empiema, timbulnya tumor pada saluran kateter, kateter tersumbat dan dislokasi kateter (Parulekar dkk, 2001; Lui dkk, 2015).

Berdasarkan jenis kateter, komplikasi akut dan lanjut lebih banyak pada pemakaian WSD dibandingkan dengan IPC, dengan komplikasi terbanyak adalah nyeri pada lokasi pemasangan kateter. Hasil penelitian ini hampir sama dengan beberapa hasil penelitian yang lain seperti penelitian Barus (2006) dan Parulekar dkk (2001), yang mendapatkan komplikasi akut yang tersering dari pemasangan WSD adalah nyeri lokasi pemasangan kateter. Pada penelitian ini terdapat hubungan yang bermakna secara statistik antara jenis kateter WSD dan IPC dengan terjadinya komplikasi akut (nilai $p=0,000$ ) dan komplikasi lanjut, tidak ditemukan hubungan yang bermakna (nilai $p=0,037)$.

Hasil penelitian lain tentang toleransi penggunaan IPC seperti penelitian Van Meter $\mathrm{dkk}^{22}$ didapatkan bahwa selama pemasangan IPC sebanyak $87,5 \%$ dari keseluruhan kasus tidak mengalami komplikasi dan walaupun terjadi komplikasi, 95,6\% kasus dapat ditatakasana dengan baik. Komplikasi ringan pada pemasangan IPC yang sering ditemukan antara lain nyeri pada lokasi pemasangan kateter yang dapat diatasi dengan pemberian analgetik $36 \%$, selulitis $3,4 \%$ dan penyumbatan kateter $3,7 \%$. Komplikasi berat jarang ditemukan, berupa empiema 2,8\% dan pneumotoraks 9,8\% (Van Meter dkk, 2011; (Park dkk, 2003). Penelitian Putnam dkk (1999), mengatakan bahwa pemakaian IPC pada pasien kanker paru dengan efusi pleura dapat menurunkan terjadinya infeksi.

Komplikasi akut dan lanjut penggunaan pigtail catheter secara keseluruhan pada penelitian ini meliputi nyeri lokasi pemasangan, masalah kateter dan infeksi. Analisis tidak dilakukan karena kecilnya jumlah subjek. Hasil penelitian lain seperti Bediwy dkk (2012), mengatakan bahwa komplikasi yang terjadi selama pemasangan pigtail catheter relatif kecil, yaitu nyeri pada lokasi pemasangan kateter yang umumnya ringan dan dapat diatasi dengan pemberian analgetik (45,09\%), penyumbatan kateter (3,92\%), infeksi (1,96\%) serta terjadinya pneumotoraks $(19,6 \%)$. Ukuran dan diameter kateter yang kecil, menjadikan pigtail catheter lebih sedikit menimbulkan rasa nyeri bila dibandingkan dengan pemasangan WSD, karena hanya sedikit menekan saraf interkostalis. Diameter kateter yang kecil 


\begin{tabular}{c|c|c}
\hline $\begin{array}{c}\text { JURNAL PENELITIAN KEPERAWATAN } \\
\text { MEDIK }\end{array}$ & VOL. 1 NO. 2 & $\begin{array}{c}\text { EDITION: NOVEMBER 2018 - } \\
\text { APRIL 2019 }\end{array}$ \\
\hline & http://ejournal.delihusada.ac.id/index.php/JPKM & \\
\hline RECEIVED: 8 JANUARI 2019 & REVISED: 10 MARET 2019 & ACCEPTED: 15 MARET 2019 \\
\hline
\end{tabular}

menyebabkan penggunaan pigtail catheter tidak dapat digunakan untuk drainase cairan tubuh yang berviskositas tinggi karena dapat menyebabkan penyumbatan lumen kateter. Penelitian oleh Parulekar dkk (2001), yang membandingkan efikasi pada 58 pasien yang terpasang pigtail catheter serta 44 pasien yang terpasang WSD, pada kanker paru dengan efusi pleura. Kedua kelompok kateter dilakukan pleurodesis dan didapatkan tidak terdapat hubungan bermakna antara kedua jenis kateter dengan komplikasi pasca pemasangan seperti terjadinya infeksi atau pneumotoraks (nilai $p=0,082$ ).

Pada penelitian ini terdapat 20 pasien yang memerlukan penggantian kateter dengan salah satu penyebab adalah timbulnya komplikasi yang tidak teratasi seperti nyeri lokasi pemasangan atau infeksi berupa empiema atau selulitis. Hasil penelitian multisenter tentang keluaran klinik pengunaan IPC yang dijelaskan pada ulasan artikel oleh Fysh dkk (2013), didapatkan komplikasi infeksi hanya 4,9\% dan secara keseluruhan 2,64\% kasus memerlukan penggantian IPC ke WSD. Hasil penelitian lainnya oleh Van Meter dkk (2011), didapatkan pasien yang memerlukan penggantian kateter dari IPC ke WSD, disebabkan komplikasi berupa pneumotoraks, yaitu sebesar 5,9\%. Pada kelompok kateter intrapleura yang memerlukan penggantian lainnya, saat ini belum ada penelitian yang membahas khusus mengenai hal ini.

\section{Lama pemakaian, lama rawat pasca pasang dan posisi pemasangan kateter}

Lama pemakaian kateter intrapleura dihitung dari tanggal pemasangan hingga tanggal pencabutan, atau bila kateter masih terpasang, maka lama pemakaian dihitung dari tanggal pemasangan sampai tanggal penelitian berakhir. Pada penelitian ini didapatkan lama pemakaian kateter terbanyak kurang dari 1 bulan. Rerata lama pemakaian 55,98 hari, median 30 hari dan range 2-310 hari. Pada penelitian ini didapatkan juga hubungan yang bermakna secara statistik antara jenis kateter (WSD dan IPC) dengan lama pemakaian kateter (WSD, nilai $p=0,002$ dan IPC, nilai $p=0,025)$. Hasil yang berbeda didapatkan pada penelitian Bediwy dkk (2012), mengenai pemakaian pigtail catheter pada efusi pleura masif, didapatkan bahwa rata-rata lama pemakaian $5,8 \pm 2,4$ hari. Pada penelitian Parulekar dkk (2001), didapatkan rata-rata lama pemakaian pigtail catheter selama 2 hari (2-28 hari), sedangkan lama pemakaian WSD rata-rata selama 6 hari (3-21 hari) serta tidak ditemukan perbedaan bermakna antara jenis kateter (pigtail catheter dan WSD terhadap lama pemakaian) dengan nilai $p=0,608$.

Lama rawat di rumah sakit setelah kateter terpasang dihitung dari tanggal pemasangan hingga tanggal pasien pulang yang berkaitan dengan pemasangan kateter intrapleura. Pada pasien yang terpasang WSD, lama rawat pasca pemasangan sama dengan lama pemakaian. Pada penelitian ini didapatkan lama rawat pasca pemasangan kateter intrapleura terbanyak adalah kurang 2 minggu dengan rerata 14,14 hari, median 10 hari dan range 1 72 hari. Lama rawat pasien yang terpasang IPC dan pigtail catheter lebih singkat dibandingkan pasien yang terpasang WSD. Pada penelitian ini juga didapatkan hubungan yang tidak bermakna antara pemasangan jenis kateter WSD dengan lama rawat pasien (nilai $\mathrm{p}=0,452$ ) dan terdapat hubungan yang berbeda bermakna antara jenis IPC dengan lama rawat (nilai $p=0,000$ ). Hasil ini sedikit berbeda dengan penelitian Parulekar dkk (2001), mendapatkan bahwa median lama rawat pasien kanker paru dengan efusi pleura yang terpasang pigtail catheter selama 12 hari (10-23 hari) dan yang terpasang WSD selama 16 hari (9-19 hari). Hasil penelitian lain oleh Putnam dkk (1999) yang membandingkan pemasangan IPC dengan pemasangan WSD dengan pleurodesis menggunakan doksisiklin, mendapatkan hasil bahwa pemakaian IPC dapat mengurangi lama perawatan di rumah sakit yaitu hanya 1 hari dibandingkan 6 hari perawatan pada kelompok pleurodesis, sehingga dapat menurunkan risiko infeksi nosokomial pada pasien kanker paru. Pada 


\begin{tabular}{c|c|c}
\hline $\begin{array}{c}\text { JURNAL PENELITIAN KEPERAWATAN } \\
\text { MEDIK }\end{array}$ & VOL. 1 NO. 2 & $\begin{array}{c}\text { EDITION: NOVEMBER 2018 - } \\
\text { APRIL } 2019\end{array}$ \\
\hline & http://ejournal.delihusada.ac.id/index.php/JPKM & \\
\hline RECEIVED: 8 JANUARI 2019 & REVISED: 10 MARET 2019 & ACCEPTED: 15 MARET 2019 \\
\hline
\end{tabular}

penelitian ini juga didapatkan total biaya perawatan di rumah sakit pada kelompok IPC lebih murah yaitu 3339 \pm 1753 Dollar berbanding $7840 \pm 4497$ Dollar pada kelompok pleurodesis. Sayangnya, karena penelitian ini bersifat retrospektif maka tidak didapatkan total biaya perawatan pasien dari masingmasing pemakaian jenis kateter.

Posisi pemasangan kateter intrapleura didasarkan pada posisi cairan pleura. Penentuan posisi cairan pleura dilakukan berdasarkan pada pemeriksaan fisis paru dan foto toraks. Pada penelitian ini karena data didapatkan dari rekam medis, maka tidak didapatkan data lengkap mengenai foto toraks pasien. Pada penelitian ini didapatkan posisi pemasangan kateter intrapleura paling banyak pada hemitoraks kana sebesar $58,4 \%$ tidak didapatkan posisi bilateral dan posisi efusi ipsilateral dengan posisi tumor. Hasil penelitian ini hampir sama dengan penelitian Castro dkk (1998), pada 78 pasien dengan efusi pleura ganas, didapatkan lokasi efusi terbanyak pada hemitoraks kanan $60 \%$ dan $40 \%$ pada hemitoraks kiri. Penelitian lainnya Antony dkk (2001), yang dibahas pada ulasan artikel oleh Antony dkk, yang melaporkan dari 122 pasien efusi pleura masif, didapatkan lokasi efusi $85 \%$ ipsilateral, $9 \%$ kontralateral dan 6\% bilateral lokasi tumor. Penelitian Mahzal dkk (2013), mendapatkan posisi pemasangan kateter intrapleura adalah pada hemitoraks kanan $52 \%$, kiri $36 \%$ dan bilateral sebanyak $12 \%$. Berdasarkan literatur, peneliti saat ini belum mendapatkan alasan yang dapat menjelaskan mengapa efusi pleura masif/ganas lebih banyak di hemitoraks kanan dibandingkan hemitoraks kiri, kecuali dengan asumsi bahwa terdapat korelasi dengan lokasi tumor primernya. Asumsi ini dapat dijelaskan dengan teori terjadinya efusi pleura pada kanker paru, yaitu peningkatan produksi cairan akibat invasi langsung sel-sel kanker ke rongga pleura, penurunan absorbsi cairan akibat obstruksi pada saluran limfe di rongga pleura oleh tumor yang besar, atau proses metastasis ke kelenjar getah bening (Miserocchi, 1997; Porcel dkk, 2006).

\section{Alasan pencabutan kateter intrapleura}

Pada penelitian ini, alasan terbanyak pencabutan kateter intrapleura adalah karena produksi cairan minimal. Alasan pencabutan lainnya meliputi meninggal dunia, komplikasi yang tidak teratasi dan pencabutan kateter atas permintaan sendiri. Pada penelitian ini juga didapatkan hubungan yang tidak bermakna secara statistik, antara pemasangan WSD dengan respons terapi (perbaikan/ produksi minimal) dengan nilai $p=0,532$. Pada penelitian ini tidak didapatkan hubungan yang tidak bermakna secara statistik antara pemasangan IPC, dengan respons terapi, dengan nilai $p=0,060$.

Hasil penelitian ini hampir sama dengan penelitian Davies dkk (2012), yang menilai respons terapi (sesak napas) pada pasien efusi pleura masif dengan pemasangan IPC dan WSD dengan pleurodesis talk. Pada penelitian ini disimpulkan bahwa terjadi perbaikan klinis sesak napas pasien, setelah pemasangan IPC dan WSD, walaupun secara statistik pada kedua jenis kateter tidak didapatkan hubungan yang bermakna.

Pada penelitian ini didapatkan juga alasan pencabutan pada pasien yang memerlukan penggantian kateter. Pada tabel penelitian yang dituliskan adalah alasan pencabutan kateter kedua. Alasan pencabutan kateter yang terbanyak adalah karena produksi cairan sudah minimal. Alasan penggantian kateter pertama kebanyakan dilakukan dengan alasan produksi cairan yang masih banyak sehingga dilakukan pemasangan kateter kedua untuk mempersingkat rawat inap pasien. Alasan penggantian lainnya adalah terjadinya komplikasi seperti nyeri lokasi kateter yang tidak teratasi dan terjadinya empiema. 


\begin{tabular}{c|c|c}
\hline $\begin{array}{c}\text { JURNAL PENELITIAN KEPERAWATAN } \\
\text { MEDIK }\end{array}$ & VOL. 1 NO. 2 & $\begin{array}{c}\text { EDITION: NOVEMBER 2018 - } \\
\text { APRIL 2019 }\end{array}$ \\
\hline & http://ejournal.delihusada.ac.id/index.php/JPKM & \\
\hline RECEIVED: 8 JANUARI 2019 & REVISED: 10 MARET 2019 & ACCEPTED: 15 MARET 2019 \\
\hline
\end{tabular}

\section{KESIMPULAN DAN SARAN}

\section{KESIMPULAN}

1. Komplikasi akut pemakaian kateter intrapleura didapatkan sebesar $70,1 \%$, yang terdiri dari nyeri di lokasi pemasangan kateter $(58,4 \%)$, infeksi $(3,9 \%)$, masalah pada selang kateter $(3,9 \%)$ dan emfisema subkutis $(3,9 \%)$.

2. Komplikasi lanjut pemakaian kateter intrapleura didapatkan sebesar 54,5\%, yang terdiri dari nyeri di lokasi pemasangan kateter yang bertambah atau menetap (29,9\%), infeksi (13\%), masalah pada selang kateter (6,5\%), hidropneumotoraks $(2,6 \%)$, alergi $(1,3 \%)$ dan emfisema subkutis (1,3\%).

3. Rerata lama rawat pasca pemasangan kateter intrapleura adalah 14,14 hari dengan median 10 hari dan range 1-72 hari. Lama rawat pasca pemasangan kateter intrapleura terbanyak kurang dari 15 hari $(66,2 \%), 15-30$ hari $(26,0 \%)$ dan lebih dari 30 hari $(7,8 \%)$.

4. Rerata lama pemakaian kateter intrapleura adalah 55,98 hari dengan median 30 hari dan range 2-310 hari. Lama pemakaian kateter intrapleura terbanyak adalah kurang dari 30 hari $(45,5 \%), 30-60$ hari $(19,5 \%)$ dan lebih dari 60 hari $(35,1 \%)$.

5. Alasan pencabutan kateter intrapleura pada penelitian ini adalah produksi cairan minimal $46,75 \%$, meninggal $26 \%$, komplikasi $15,6 \%$, dan kateter dicabut atas permintaan sendiri 2,6\%. Pada penelitian ini sebanyak 7 pasien $(9,1 \%)$ kateter masih terpasang.

\section{SARAN}

1. Perlu penelitian observasional berdesain prospektif dengan jumlah sampel yang sama pada jenis kateter yang akan diteliti, sehingga penggunaan ketiga jenis kateter (WSD, IPC dan pigtail catheter) dalam hal toleransi dan efikasi dapat dianalisis perbandingannya.

2. Perlu dilakukan penelitian dengan kelompok pembanding seperti tindakan pleurodesis, yang saat ini merupakan pilihan tatalaksana kanker paru dengan efusi pleura yang banyak digunakan.

\section{DAFTAR PUSTAKA}

American Thoracic Society. 2000. Management of malignant pleural effusion. Am J Respir Crit Care Med.,162:1987-97.

Mangunnegoro H. 1998. Masalah efusi pleura di Indonesia. J Respir Indo, 18:48-50.

Syahruddin E, Pratama AD, Arief N. 2010. A retrospective study: clinical and diagnostic characteristics in advanced stage of lung cancer patients with pleural effussion in Persahabatan Hospital 2004-2007.J Respir Indo.; 30:146-50.

Mahsal F, Syahruddin E, Soehardiman D. 2013. Angka tahan hidup penderita kanker paru berdasarkan kepositifan sitologi cairan pleura dan atau histopatologi biopsi pleura (Tesis). Fakultas Kedokteran Universitas Indonesia.

Syahruddin E. 2013. The management of malignant pleural effusions. Perhimpunan Dokter Paru Indonesia. Konas PDPI Lampung.

Lee G, Fysh ET, Waterer GW, Kendall PA, Bremner PR, Dina S, et al. 2012. Indwelling pleural catheters reduce inpatient days over pleurodesis for malignant pleural effusion. Chest.; 142(2):394-400.

Gammie JS, Banks MC, Fuhrman CR, Pham SR, Griffith BP, Keenan RJ, et al. 1999. The pigtail catheter for pleural drainage : a less invasive alternative to tube thoracostomy. JSLS.; 3:57-61.

Antunes G, Neville E, Duffy J, Ali N. 2003. BTS guidelines for the management of malignant pleural effusions. Thorax.; 58(suppl II): 29-38.

Miserocchi G. 1997. Physiology and pathophysiology of pleural fluid turnover. Eur Respir J.; 10:219-25.

Porcel JM, Light RW. 2006. Diagnostic approach to pleural effusion in adults. Am Fam Physician.; 73:1211-20.

Barus FA, Hudoyo A, Swidarmoko B. 2006. Perbandingan keberhasilan pleurodesis povidon iodin dengan doksisiklin pada efusi pleura ganas. J Respir Indo.; 26(2):69-85.

Van Meter ME, McKee KY, Kohlwes RJ. 2011. Efficacy and safety of tunneled pleural catheters in adult with malignant pleural 


\begin{tabular}{c|c|c}
\hline $\begin{array}{c}\text { JURNAL PENELITIAN KEPERAWATAN } \\
\text { MEDIK }\end{array}$ & VOL. 1 NO. 2 & $\begin{array}{c}\text { EDITION: NOVEMBER 2018 - } \\
\text { APRIL 2019 }\end{array}$ \\
\hline & http://ejournal.delihusada.ac.id/index.php/JPKM & \\
\hline RECEIVED: 8 JANUARI 2019 & REVISED: 10 MARET 2019 & ACCEPTED: 15 MARET 2019 \\
\hline
\end{tabular}

effusions: a systematic review. J Gen Intern Med.; 26:70-6.

Putnam JB, Light RW, Rodriguez RM. 1999. A randomized comparison of indwelling pleural catheter and doxycycline pleurodesis in the management of malignant pleural effusions. Cancer; 86:1992-9.

Bediwy AS, Amer HG. 2012. Pigtail catheter use for draining pleural effusions of various etiologies. ISRN Pulmonology.; 8:77-83.

Parulekar W, Di Primio G, Matzinger F, Dennie C. 2001. Use of small-bore vs large bore chest tubes for the treatment of malignant pleural effusions. Chest.; 120:19-25.

Lui MM, Thomas R, Lee YCG. 2015. Complication of indwelling pleural catheter use and their management. BMJ.; 10:1-7.

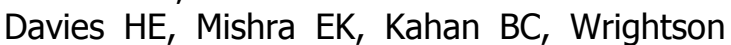
JM, Stanton AE, Guhan A, et al. 2012. Effect of an indwelling pleural catheter vs chest tube and talc pleurodesis for relieving dyspnea in patients with malignant pleural effusion. JAMA.; 307:2383-9.

Trembley A, Michaud G. 2006. Single center experience with 250 tunnelled pleural catheter insertions for malignant pleural effusion. Chest.; 129(2):362-8.

Bielsa S, Salud A, Martinez M, Esquerda A, Martin A, Rodriquez P, et al. 2008. Prognostic sifnificance of pleural fluid data in patients with malignant effusion. Eur J Int Med.; 19:334-9.

Sallach SM, Sallach JA, Vasques E, Shultz I, Levak P. 2002. Volume of pleural fluid required for diagnosis of pleural malignancy. Chest.; 122:1913-7.

Park JO, Lee SI, Song SY, Kim K, Kim WS, Jung CW, et al. 2003. Measuring response in solid tumors : comparison of RECIST and WHO response criteria. Jpn J Clin Oncol.; 33:533-7.

Fysh ET, Tremblay A, Feller-Kopman D, et al. 2013. Clinical outcome of indwelling pleural catheter-related pleural infections:an international multicenter study. Chest.; 144:1597-602.

Castro DJ, Nuevo GN, Rodriquez EP. 1998. Cytologically proved malignant pleural effusion. Chest.; 1798-9.

Antony VB, Loddenkeper R, Astoul D, Boutin C, Golsstraw P, Holt J, et al. 2001. ERS/ATS statement: Management of malignant pleural effusin. Eur Respir J.; 18:402-19. 